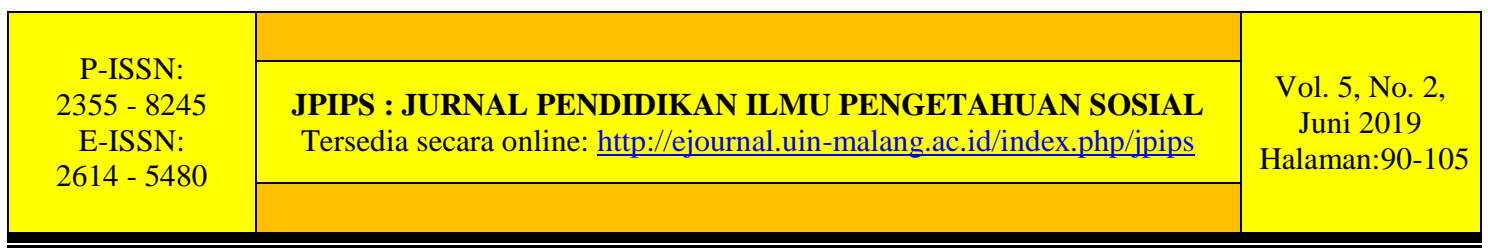

\title{
PERAN PENDIDIKAN NON FORMAL BERBASIS SOSIAL EKONOMI DALAM ORGANISASI SOSIAL PREMAN SUPER DI MALANG RAYA
}

\author{
Dwi Sulistiani \\ UIN Maulana Malik Ibrahim Malang \\ dwisulistiani@pips.uin-malang.ac.id
}

\begin{abstract}
Abstrak: Penelitian dengan metode kualitatif deskriptif ini bertujuan untuk mengetahui bagaimana peran pendidikan non formal berbasis sosial ekonomi dalam organisasi Preman Super di wilayah Malang Raya. Hasil penelitian menunjukkan bahwa Preman Super sudah menerapkan nilai-nilai pendidikan dengan membagi dua macam jenis, yaitu pendidikan internal dan eksternal, yang dimaksud dengan pendidikan internal adalah para anggota perempuan diberikan pelatihan, dibekali ilmu pengetahuan dan juga diberikan kebebasan untuk mengasah keterampilan sesuai dengan potensi yang dimilikinya. Pendidikan internal yang lain adalah program trainer of trainer atau istilahnya adalah anggota yang sudah mahir/berpengalaman bisa memberikan pelatihan kepada anggota baru, hal itu sesuai dengan konsep dan proses pemberdayaan. Pendidikan eksternal yakni beberapa anggotanya yang sudah memiliki pengalaman atau memiliki keahlian tertentu akan diikutsertakan dalam pelatihan-pelatihan yang diadakan oleh dinas terkait yang telah menjadi mitra kerja dari Preman Super. Dalam pelatihan itu para anggota diberikan kesempatan untuk mengembangkan bakat sesuai bidangnya, sebagai misal, para anggota yang hobi pada bidang memasak, maka mereka akan diikutsertakan pada pelatihan memasak dari dinas terkait dan dilakukan setiap bulan sekali. Pendidikan non formal yang dilakukan oleh organisasi sosial Preman Super terbukti efektif dalam meningkatkan pemberdayaan perempuan di wilayah malang raya
\end{abstract}

Kata kunci: pendidikan non formal, sosial ekonomi, organisasi sosial, preman super, malang raya

Abstract: This research with descriptive qualitative method aims to determine how the role of socio-economic-based non-formal education in the organization of Preman Super in the Greater Malang region. The results showed that Preman Super had implemented educational values by dividing two types, namely internal and external education, which meant internal education was that women members were given training, provided with knowledge and were also given the freedom to hone skills according to their potential. it has. Other internal education is a trainer of trainer program or the term is that advanced members can provide training to new members, in accordance with the concept and process of empowerment. External education, which is a number of members who already have experience or have certain skills, will be included in the training held by related agencies that have become partners of Preman Super. In the training the members were given the opportunity to develop talents according to their fields, for example, members who like to cook, then they will be included in cooking training from related agencies and conducted every month. Non- 
formal education carried out by social organizations Preman Super proved effective in increasing women's empowerment in the poor region

Key words: non-formal education, socio-economic, social organization, preman super, poor

\section{PENDAHULUAN}

Indonesia adalah negara yang sedang berkembang ke arah modernisasi. Seiring dengan laju pertumbuhan ekonomi, semakin terlihat pembangunan yang berkelanjutan dan meluasnya indrustrialisasi. Proses pembangunan yang terjadi di Indonesia dipengaruhi oleh dua dimensi, pertama adalah dimensi makro yang menggambarkan bagaimana institusi negara melalui kebijakan dan peraturan yang dibuat untuk mempengaruhi proses perubahan suatu masyarakat. Sedangkan kedua adalah dimensi mikro yaitu individu dan kelompok masyarakat yang mempengaruhi proses pembangunan itu sendiri (Rukminto, 2003).

Negara memiliki tugas dan tanggung jawab yang besar dalam mendorong kemajuan pendidikan nonformal untuk membantu kesejahteraan masyarakat. Pendidikan nonformal sebagai sumber pembelajaran kepada masyarakat harus dapat dilihat sebagai daya dukung terhadap realisasi dan pengelolaan program, dan dijadikan sebagai pengembangan program di masa yang akan datang. Peran masyarakat sebagai sasaran, dapat dilihat pada tingkat partisipasi masyarakat dalam mengikuti berbagai program yang berhubungan dengan peningkatan keterampilan, kemampuan, dan kualitas dirinya sehingga mampu meningkatkan kesejahteraan sosial masyarakat di daerah tersebut.

Pendidikan nonformal sebagai salah satu pendekatan dalam pembangunan, akan bisa membuat manusia menjadi lebih maju, berkualitas, dihargai di mata sosial, dan memiliki daya saing tinggi, dan pada akhirnya akan dapat meningkatkan derajat hidup sosial masyarakat dan dapat meningkatkan produktivitas kerja secara personal maupun secara nasional demi kemajuan bangsa dan negara. Konsep pendidikan nonformal merupakan konsep pendidikan dan pembelajaran yang berbasis pada masyarakat dengan tujuan agar masyarakat yang tidak menikmati pendidikan pada lembaga pendidikan formal, bisa mendapatkan di lembaga pendidikan nonformal, dengan harapan bisa dapat merubah pola pikir masyarakat dan dapat meningkatkan kehidupannya. Sehingga dapat terbentuk kesadaran ingin berusaha dan berjuang untuk merubah hidupnya melalui proses pendidikan nonformal masyarakat dapat diberdayakan.

Pendidikan nonformal bagi perempuan harus berpusat pada perempuan dengan bertitik tolak dari perempuan, dilaksanakan oleh perempuan dan manfaatnya untuk pemberdayaan perempuan. Jadi "Proses" akan menunjukkan pada suatu tindakan nyata yang harus dilakukan secara bertahap untuk dapat mengubah kondisi masyarakat yang lemah, baik dari aspek knowledge, attitude, maupun practice menuju pada penguasaan pengetahuan, sikap perilaku sadar dan kecakapan keterampilan yang baik agar masyarakat dapat berdayakan untuk meningkatkan taraf kehidupan mereka dari kehidupan yang sebelumnya.

Penelitian yang dilakukan oleh Mirajd dan Sumarno (2014) menunjukkan bahwa pendidikan formal belum sesuai harapan masyarakat, belum sesuai dengan kebutuhan masyarakat dampingan, belum bisa membantu meningkatkan kehidupan warga miskin dan hubungan kerjasama organisasi sosial hanya sebatas pemerintah daerah saja. Sedangkan penelitian yang dilakukan oleh Hidayat, Anwar dan Hidayah (2017) 
menunjukkan hasil yang lebih positif dimana pendidikan non formal bagi anak-anak jalanan bisa menginkatkan ketrampilan mereka di bidang kesenian music dengan cara memberikan pendampingan, menyediakan alat-alat musik, pemberian dukungan minat dan bakat yang dimiliki anak-anak jalanan. Hasil penelitian serupa juga dialami oleh Wulandari (2016) dimana pendidikan non formal di bidang seni tari memberikan hasil yang positif dengan cara penyampaian secara informal serta keakraban guru dan peserta pendidikan formal tersebut. Metode demonstrasi terbukti efektif dalam penyampaian materi seni tari sehingga peserta didik mudah dalam menghafal dan memperagakan sebuah tarian.

Berdasarkan penelitian diatas menunjukkan bahwa pendidikan non formal bisa sangat efektif dalam pemberdayaan masyarakat jika dilakukan dengan baik dan sesuai dengan kebutuhan masyarakat, tapi pendidikan nonformal juga bisa kurang efektif saat penggagas kegiatan tersebut memaksakan kegiatannya tanpa melihat kebutuhan masyarakat. Organisasi sosial preman super merupakan salah satu organisasi sosial yang bertujuan untuk memberdayakan perempuan khususnya di Malang Raya. Penelitian ini akan melihat bagaimana peran pendidikan non formal berbasis sosial ekonomi yang dilakukan oleh organisasi sosial preman super dalam memberdayakan perempuan di Malang Raya.

Pembangunan merupakan sebuah pendekatan yang dilakukan untuk meningkatkan kesejahteraan manusia yang dikenal dengan istilah pembangunan sosial. Pendekatan pembangunan sosial merupakan suatu pendekatan yang unik yang mengintegrasikan tujuan ekonomi dan sosial, hal tersebut selaras dengan amanat UUD 1945 dengan tujuan utamanya adalah memajukan kesejahteraan umum dan mencerdaskan kehidupan bangsa. Dalam definisi lain juga dijelaskan bahwa pengembangan masyarakat adalah salah satu metode pekerjaan sosial yang tujuan utamanya untuk memperbaiki kualitas hidup masyarakat melalui pendayagunaan sumber-sumber yang ada pada mereka serta menekankan pada prinsip dan partisipasi social (Suharto, 2009: 59).

Meningkatnya kemiskinan dan pengangguran yang saat ini terjadi menuntut semua pihak merumuskan kembali strategi pembangunan yang sesuai untuk diterapkan di negeri ini. Sehingga tidak terdapat lagi masyarakat yang tergeser, terjepit, dan terpinggirkan. Dengan pemahaman seperti itu, pembangunan disejajarkan dengan kata perubahan sosial. Dalam pengertian seperti ini teori pembangunan berarti teori sosial ekonomi yang sangat umum. Pandangan ini menjadi pandangan yang menguasai hampir setiap diskursus mengenai perubahan social (Faqih, 2003: 10).

Pembangunan bidang ekonomi adalah salah satu strategi untuk mencapai tujuan yang dicita-citakan bangsa ini. Bidang ekonomi adalah salah satu bidang yang menjadi perhatian serius dan sangat strategis karena berkaitan langsung dengan kehidupan sehari-hari masyarakat. Indikator keberhasilan pembangunan suatu negarapun dapat dilihat pada ketercapaian target-target ekonominya. Pertumbuhan ekonomi, pendapatan perkapita penduduk, jumlah pengangguran, tingkat kemiskinan, dan neraca pembayaran adalah ukuran-ukuran yang dicapai dalam menilai tingkat keberhasilan pembangunan ekonomi (Baswir, 2009: 7-8).

Kesejahteraan, pertumbuhan, dan perkembangan per-ekonomian adalah tujuan pembangunan yang dilaksanakan oleh negara-negara berkembang termasuk Indonesia. Pembangunan ekonomi dinegara-negara berkembang tersebut pada saat ini mengalami banyak kegagalan. Ditengah kegagalan pembangunan yang berlandaskan pada sistem kapitalisme dunia ini muncullah sebuah alternatif sistem ekonomi yang berbasiskan 
pada nilai-nilai ajaran syari'ah Islam. Meskipun pada kenyataannya ajaran Islam memberikan petunjuk-petunjuknya dalam beraktivitas ekonomi tetapi secara bangunan ilmu masih membutuhkan proses untuk menjadi mapan. Disisi lain ajaran syari'ah Islam memang menuntut para pemeluknya untuk berlaku secara professional yang dalam prosesnya menampilkan kerapian, kebenaran, ketertiban, dan keteraturan (Hafidudin dan Tanjung, 2003:1).

Pengertian diatas menjelaskan bahwa sebenarnya agama Islam berperan penting dalam pembangunan masyarakat bukan hanya tentang sosial dan ekonomi saja, tetapi juga mencakup seluruh dimensi kehidupan. Dalam hal ini penulis mencoba mengaitkan antara hubungan antara materi pengembagan sosial ekonomi dalam perspektif Islam dengan skripsi penulis yakni tentang pemberdayaan yang sebenarnya sudah cukup jelas, memiliki karakteristik yang sama, hanya saja dibedakan oleh kata pengembangan dan pemberdayaan, tetapi pada dasarnya istilah tersebut mengandung unsur yang saling berkaitan dan berorientasi pada kesejahteraan masyarakat.

Pemberdayaan merupakan aspek mualamalah yang sangat penting karena terkait dengan pembinaan dam perubahan masyarakat. Di dalam Al Qur'an dijelaskan betapa pentingnya sebuah perubahan, perubahan itu dapat dilakukan dengan salah satu cara di antaranya pemberdayaan yang dilakukan oleh agen pemberdayaan. Sebagaimana firman Allah dalam surat Ar -Ra'd ayat 11:

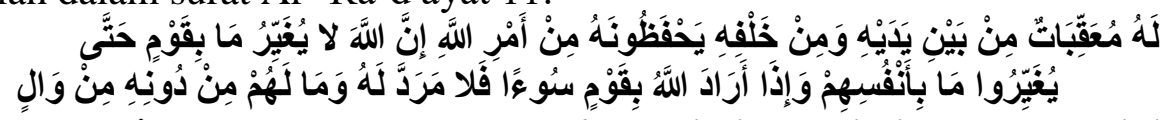

Artinya: "Bagi manusia ada malaikat-malaikat yang selalu mengikutinya bergiliran, di muka dan di belakangnya, mereka menjaganya atas perintah Allah. Sesungguhnya Allah tidak mengubah keadaan sesuatu kaum sehingga mereka mengubah keadaan yang ada pada diri mereka sendiri. Dan apabila Allah menghendaki keburukan terhadap sesuatu kaum, maka tak ada yang dapat menolaknya; dan sekali-kali tak ada pelindung bagi mereka selain Dia”.

Jadi kesimpulannya adalah, bahwa pemberdayaan atau pengembangan dalam Islam sangat diutamakan karena agama Islam telah mengajarkan kepada manusia tentang kerja keras, tidak berputus asa dan selalu berusaha hingga Allah SWT memberikan hasil yang telah dijanjikanNya.

Pendidikan non formal dengan berbagai atribut dan nama atau istilah lainnya, baik disebut dengan mass education, adult education, lifelong education, learning society, out-of-school education, social education dll merupakan kegiatan yang terorganisir dan sistematis yang diselenggarakan diluar sub-sistem pendidikan formal (Kamil, 2009: 13).

Pengungkapan istilah pendidikan non formal memberikan informasi bahwa pada hakikatnya pendidikan tidak hanya diselenggarakan di pendidikan formal saja, tetapi juga di pendidikan non formal. Hal ini sesuai dengan UU Republik Indonesia No. 20 tahun 2003 tentang Sistem Pendidikan Nasional, pasal 1 ayat (10) Satuan Pendidikan adalah kelompok layanan pendidikan yang menyelenggarakan pendidikan pada jalur formal, non formal, dan informal pada setiap jenjang dan jenis pendidikan; ayat (11) Pendidikan Formal adalah jalur pendidikan yang terstruktur dan berjenjang yang terdiri atas pendidikan dasar, menengah, dan pendidikan tinggi; ayat (12) Pendidikan Non Formal adalah jalur pendidikan di luar pendidikan formal yang dapat dilaksanakan secara terstruktur dan berjenjang; ayat (13) Pendidikan Informal adalah jalur pendidikan keluarga dan lingkungan (Kamil, 2009: 15). 
Pendidikan non formal diselenggarakan melalui tahapan-tahapan pengembangan bahan belajar, pengorganisasian kegiatan belajar, pelaksanaan belajar mengajar dan penilaian. Hal ini sejalan dengan pendapat Knowles, bahwa langkah-langkah pengelolaan kegiatan belajar meliputi: (a) menciptakan lingkungan yang kondusif untuk belajar; (b) menetapkan struktur organisasi pengelola program belajar; (c) mengidentifikasi kebutuhan belajar; (d) merumuskan arah dan tujuan belajar; (e) menyusun pengembangan bahan belajar; (f) melaksanakan kegiatan belajar; dan (g) melakukan penilaian (Kamil, 2009: 16).

Dari uraian diatas dapat ditarik kesimpulan bahwa pendidikan non formal merupakan jalur pendidikan yang terstruktur dan berjenjang serta memiliki tahapan pengembangan bahan belajar, pelaksanaan kegiatan belajar, pengelola program belajar dan penilaian belajar.

Seperti diketahui secara umum, definisi dari pendidikan non formal merupakan istilah jenjang pendidikan yang dilakukan diluar sekolah atau pendidikan formal sebagai salah satu sub sistem pendidikan yang memberikan layanan khusus pada warga belajar untuk membantu mengidentifikasi kebutuhan belajar dan mencapai tujuan belajarnya. Berikut ini diuraikan berbagai definisi tentang pendidikan non formal yang dikemukakan para ahli:

1. Pendidikan non formal adalah usaha yang terorganisir secara sistematis dan kontinyu diluar sistem persekolahan, melalui hubungan sosial untuk membimbing individu, kelompok dan masyarakat, agar memiliki sikap dan citacita sosial (yang efektif) guna meningkatkan taraf hidup dibidang materi, sosial dan mental dalam rangka usaha mewujudkan kesejahteraan sosial (Hamojoyo).

2. Suatu kegiatan pendidikan yang terorganisasi, diselenggarakan diluar pendidikan persekolahan, diselenggarakan secara tersendiri atau merupakan bagian penting dari suatu kegiatan yang lebih luas dengan maksud memberikan layanan khusus kepada warga belajar didalam mencapai tujuan belajar (Phillip H. Coombs).

3. Pendidikan non formal didefinisikan untuk tujuan kami sebagai metode untuk menilai kebutuhan akhir minat orang dewasa dan remaja putus sekolah di negara berkembang untuk berkomunikasi dengan mereka, memotivasi mereka untuk pola, dan kegiatan terkait yang akan meningkatkan produktivitas mereka dan meningkatkan standar hidup mereka (Niehoff).

Dari beberapa definisi diatas dapat disimpulkan bahwa pendidikan non formal dalam proses penyeleggaraannya memiliki suatu sistem yang terlembagakan, yang didalamnya terkandung makna bahwa setiap pengembangan pendidikan nonformal perlu perencanaan program yang matang, isi program, saran prasarana, sasaran didik dan sumber belajar, serta faktor-faktor yang satu sama lain tak dapat dipisahkan dalam pendidikan nonformal (Kamil, 2009: 14). Pengertian diatas sama halnya dengan apa yang terjadi dalam organisasi sosial Preman Super yakni perlunya sebuah inisiasi, perencanaan program yang matang, isi program, saran prasarana, sasaran didik dan sumber belajar, yang akhirnya memberikan sebuah nilai dan juga keterampilan dari masing-masing perempuan yang mempunyai tekad yang sama, yakni terbebas dari belenggu kemiskinan dan menuju kesejahteraan hidup melalui pengalaman yang mereka dapat.

Sedangkan pentingnya peran pendidikan nonformal dimasyarakat bisa dianalisis dari jenis kebutuhan belajar yang beragam, hal inii sejalan dengan pendapat para ahli dibidang pendidikan nonformal. Lebih jauh, Coombs mengungkapkan bahwa program belajar bagi masyarakat pedesaan didunia ketiga dapat dikelompokkan kedalam: (a) 
Pendidikan umum atau dasar, meliputi program literasi, pengertian dasar mengenai ilmu pengetahuan dan lingkungan, dan sebagainya; (b) Pendidikan kesejahteraan keluarga, terutama dirancang untuk menyebarkan pengetahuan, keterampilan dan sikap yang bermanfaat bagi kesejahteraan keluarga; (c) Pendidikan kemasyarakatan; dan (d) pendidikan kejuruan. Sedangkan Herbinson yang dikutip Simkins mengajukan pengelompokan program belajar pendidikan nonformal berdasar atas peningkatan produktivitas kerja yaitu: (a) program peningkatan pengetahuan dan keterampilan bagi masyarakat yang telah bekerja; (b) program penyiapan angkatan kerja, terutama bagi masyarakat yang belum bekerja; dan (c) program untuk mengembangkan pengetahuan, keterampilan, dan pemahaman diluar dunia kerja (Kamil, 2009: 17).

Berdasarkan kondisi-kondisi diatas program pendidikan nonformal dapat dikelompokkan kedalam 2 hal, yakni:

1. Program pendidikan dasar, yang memberikan pelayanan belajar kepada masyarakat yang belum memiliki kemampuan-kemampuan dasar seperti program literasi.

2. Program pendidikan lanjutan, yang memberikan pelayanan pendidikan untuk mengembangkan dan meningkatkan pengetahuan dan keterampilan kejenjang yang lebih tinggi, seperti: pendidikan untuk peningkatan produktivitas kerja. Dalam hal ini program pendidikan yang dilakukan oleh organisasi Preman Super adalah dengan memberikan pelayanan program pendidikan dasar, yakni memberikan transfer ilmu pengetahuan kepada perempuan guna menggali kreativitas dan bakat yang dimiliki oleh setiap perempuan agar perempuan memiliki kemampuan dan daya saing.

Tugas Pendidikan Non Formal adalah membantu kualitas dan martabat sebagai individu dan warga negara yang dengan kemampuan dan kepercayaan pada diri sendiri harus dapat mengendalikan perubahan dan kemajuan (Joesoef, 1992: 85). Tugas Pendidikan Non Formal berarti sejalan dengan amanat yang telah ditetapkan dalam UUD 1945 dengan salah satu tujuannya adalah memajukan kesejahteraan umum dan mencerdaskan kehidupan bangsa. Inti pembangunan yang digariskan dalam GBHN dan Pendidikan Nasional.

Didalam pelaksanaannya, program pendidikan Non Formal harus memenuhi syarat-syarat sebagai berikut:

1. Pendidikan Non Formal harus jelas tujuannya

2. Ditinjau dari segi masyarakat, program pendidikan non formal harus menarik baik hal yang akan dicapai maupun cara-cara melaksankannya.

3. Adanya integrasi pendidikan non formal dengan program-program pembangunan masyarakat (Joesoef, 1992: 85).

Kontribusi pendidikan nonformal dalam pemberdayaan masyarakat, secara lebih jelas dapat dilihat dari definisi dan hakikat peran pendidikan nonformal itu sendiri. Dari beberapa definisi yang telah diuraikan terdahulu nampak ada beberapa kesamaan peran pendidikan nonformal dan pendidikan sosial dalam memberdayakan masyarakat. Kesamaan peran tersebut dapat dilihat dari: (a) hakikat pendidikan nonformal adalah membelajarkan masyarakat yang dilakukan diluar sistem pendidikan formal, (b) kegiatan pembelajaran dalam pendidikan nonformal merupakan aktivitas yang disengaja dan diorganisasi secara sistematis untuk mencapai tujuan tertentu, (c) sesuai dengan fungsi pendidikan nonformal sasarannya adalah semua warga masyarakat dalam membantu membelajarkan (pemerataan pendidikan), dan (d) bertujuan memberikan 
bekal pengetahuan, sikap dan keterampilan dalam rangka meningkatkan taraf hidup dan pengembangan SDM sebagai modal pembangunan nasional.

Sudjana (1989: 162) secara lebih tegas menerangkan tugas pendidikan non formal adalah: (a) membelajarkan warga belajar agar mereka memiliki dan mengembangkan keterampilan, sikap, pengetahuan, nilai-nilai dan aspirasi untuk mengantisipasi pemungkinan perubahan dimasa depan, dan (b) membelajarkan warga belajar agar mereka mampu meningkatkan dan memanfaatkan SDA guna meningkatkan taraf hidupnya (Kamil, 2009: 54).

Berdasarkan teori diatas, maka penulis dapat menyimpulkan bahwa kaitan teori diatas dengan realita dilapangan adalah sejalan dan selaras karena penulis melihat dari sisi peran dan tugas pendidikan nonformal yang telah disebutkan. Jadi dapat dikatakan bahwa pada dasarnya organisasi sosial Preman Super telah mencakup peran maupun tugas pendidikan nonformal yakni pemberdayaan masyarakat.

Ilmu sosial dan Ilmu Pengetahuan Sosial itu memiliki perbedaan yang sangat tipis tetapi secara elementer memiliki persamaan yakni mempelajari suatu ruang lingkup Sosial. Dan peran Ilmu Sosial bagi pengembangan Sosial Ekonomi masyarakat adalah banyaknya sumbangsih yang diberikan, sebagai salah satu contoh adalah dari aspek pengetahuan dan pembentukan nilai dan sikap yang berasaskan nilai-nilai pancasila yang merupakan hakikat Ilmu Sosial. Juga bisa dilihat dari ruang ligngkupnya yang luas, mulai dari Sejarah, Antropologi, Sosiologi, Ekonomi, Politik, Geografi, Psikologi maupun Filsafat. Namun jika bicara tentang peran Sosial dan Ekonomi bagi masyarakat Ilmu Sosial telah berperan banyak. Sebagai contoh masyarakat desa yang memiliki tradisi yang disebut Gemeinschaft (paguyuban) dan Geisselshaft (Patembayan) atau secara istilahnya adalah masyarakat yang berkumpul, gotong royong, mengenal toleransi antar agama, bersosialisasi dan saling berkomunikasi mapun berinteraksi dengan individu lain. Dari sisi ekonomi, masyarakat mampu mengenal adanya utang piutang, jual beli, debet dan kredit dan perbankan yang semua itu adalah ruang lingkup ekonomi.

Pengertian diatas telah menunjukkan bahwa peran Ilmu Sosial bagi pengembangan Sosial Ekonomi masyarakat adalah memiliki peran yang besar. Disini penulis mencoba menerangkan kaitan materi dengan judul skripsi "Peran Pendidikan Non Formal Berbasis Sosial Ekonomi dan Pemberdayaan Perempuan dalam Organisasi Sosial Preman Super di Malang Raya" yang memiliki peran besar dalam pengembangan Sosial Ekonomi dalam Masyarakat khususnya perempuan. Penulis bisa mengatakan demikian karena dalam organisasi tersebut perempuan yang awalnya hanya sebagai ibu rumah tangga biasa dan pemulung, disana mereka diberikan pelatihan maupun pengetahuan melalui program yang disediakan untuk mengembangkan potensi masing-masing individu. Selain itu mereka juga diajarkan bersosialisasi antar anggota agar memiliki keberanian berbicara didepan publik sesuai dengan tujuannya yakni pengentasan kemiskinan dan kesejahteraan bagi masyarakat.

\section{METODE}

Penelitian ini menggunakan pendekatan kualitatif dan jenis penelitian yang digunakan adalah studi kasus, dengan pendekatan ini maka peneliti menggali lebih mendalam tentang fokus penelitian di organisasi sosial Preman Super sehingga nantinya dapat diperoleh kesimpulan tentang peran pendidikan non formal berbasis sosial 
ekonomi dalam organisasi sosial Preman Super. Objek penelitian ini beralamat di Jln. Plaosan Timur Gg. Lori No. 5 RT 06 RW 09, Kecamatan Blimbing Kota Malang.

Penelitian ini menggunakan data primer dan data sekunder. Data primer diperoleh dari wawancara pada pembina sekaligus pendiri organisasi Preman Super untuk menggali informasi tentang peran pendidikan non formal berbasis ekonomi sosial dalam organisasi preman super. Data sekunder diperoleh melalui internet, foto, profil organisasi serta literatur terkait penelitian ini.

Teknik pengumpulan data yang digunakan adalah wawancara, observasi dan dokumentasi. Wawancara digunakan untuk mencari dan menggali informasi tentang peran pendidikan non formal berbasis sosial ekonomi dalam organisasi Preman Super. Penelitian ini dilakukan secara langsung dengan responden dan direkam. Observasi dilakukan untuk mendapatkan data tentang bagaimana peran organisasi sosial Preman Super dalam pengembangan sosial ekonomi dan pemberdayaan perempuan. Jadi dari data observasi dapat diketahui bagaimana peran pendidikan non formal berbasis sosial ekonomi dalam organisasi Preman Super. Dokumen yang digunakan oleh peneliti untuk memperoleh data adalah berupa laporan kegiatan, laporan anggota, dan juga foto selama kegiatan pelatihan dan juga rapat anggota. Teknik penelitian dilakukan oleh peneliti adalah untuk mencari sumber data tertulis seperti profil organisasi serta data-data yang tersedia dalam organisasi tersebut.

Dalam penelitian ini, teknik analisis yang digunakan peneliti adalah teknik analisa deskriptif kualitatif (berupa kata-kata dan bukan dengan angka). Penyajian data (display data) disajikan dalam bentuk tulisan, bagan, dan sejenisnya. Penyajian data sebagai kesimpulan informasi yang tersusun dan memberi kemungkinan adanya pengambilan kesimpulan. Dengan demikian penyajian data harus apa yang harus dipahami dan dilakukan lebih jauh. Langkah terakhir dalam penelitian kualitatif adalah penarikan kesimpulan. Kesimpulan (conclusion) ditarik dari hasil penafsiran dan evaluasi. Penyajian data yang telah didukung oleh data-data yang mantap maka dapat disimpulkan.

Pelaksanaan penelitian yang dilakukan di organisasi sosial Preman Super Kota Malang dilakukan dengan tahapan sebagai berikut:

1. Tahap pra penelitian. Meliputi kegiatan penentuan fokus penelitian, memilih lapangan penelitian, permohonan izin kepada subyek yang akan diteliti, penelitian pendahuluan, dan penyusunan usulan penelitian.

2. Tahap penelitian. Memahami latar penelitian, mengumpulkan bahan yang akan digunakan untuk subyek penelitian yang berkaitan dengan peran organisasi sosial Preman Super, memasuki lapangan, peran serta dan pengumpulan data melalui teknik wawancara, observasi, dan dokumentasi.

3. Tahap analisis data. Kegiatan analisis data yang diperoleh melaui wawancara, observasi, maupun dokumentasi dengan pendiri organisasi sosial Preman Super, kemudian dilakukan penafsiran data hingga pengecekan keabsahan data dengan cara mengecek sumber data yang diperoleh sehingga data benar-benar valid dan akurat sebagai syarat pemberian makna data yang merupakan proses dalam penelitian yang sedang diteliti. 


\section{HASIL DAN PEMBAHASAN}

\section{Hasil}

Organisasi sosial Preman Super di Kota Malang didirikan atas dasar keinginan sekelompok perempuan yang ingin memberdayakan perempuan lainnya yang membutuhkan. Organisasi ini berdiri berkat adanya inisiasi dari perkumpulan ibu-ibu pada tahun 2010 untuk membentuk sebuah organisasi, tetapi hal tersebut baru dapat terlaksana pada tahun 2013. Organisasi sosial tersebut diberi nama Preman Super (Perempuan Mandiri Sumber Perubahan) yang didirikan di Kota Malang.

Ide terbentuknya organisasi Preman Super berawal dari sebuah perkumpulan ibu-ibu rumah tangga dengan tujuan awal untuk bertukar ilmu dan bertukar keterampilan. Tetapi, seiring berjalannya waktu semakin banyak orang yang tertarik untuk berkumpul dan mereka menemukan dampak serta manfaat dari perkumpulan itu. Dari yang awalnya hanya ibu rumah tangga biasa, melalui perkumpulan itu akhirnya mereka bisa mengetahui potensi yang dimilikinya dan memiliki kesempatan untuk mengembangkan potensinya.

Organisasi Sosial Preman Super memiliki peran penting bagi perempuan untuk menyalurkan bakat dan minat serta mengasah potensi yang dimilikinya agar kelak bisa menciptakan sesuatu yang bernilai jual serta diharapkannya dari suatu organisasi sosial tersebut mampu menghasilkan perempuan-perempuan yang tangguh, memiliki skill, dan mandiri secara finansial serta menjadi sumber perubahan bagi masing-masing keluarganya, memiliki kecakapan didepan publik, tidak minder dan memiliki rasa percaya diri sesuai dengan harapan dari Ibu Peni Budi Astuti selaku pendiri dan pembina organisasi sosial Preman Super Kota Malang.

Saat ini Organisasi Preman Super telah memiliki anggota yang jumlahnya \pm 200 anggota yang didominasi oleh perempuan, yang masih aktif sebagai anggota berjumlah \pm 120 orang. Selain perempuan ada juga anggota yang berjenis kelamin laki-laki. Tetapi secara strukutur kepengurusan organisasi, yang memiliki hak adalah perempuan dikarenakan backgroundnya adalah organisasi yang berbasis pemberdayaan perempuan. Organisasi Preman Super memberikan pelatihan kepada anggotanya, diantaranya adalah pelatihan tentang memasak, handicraft (kerajinan tangan) dan kesenian. Dampak dari adanya organisasi sosial Preman Super adalah adanya perubahan secara signifikan pada hal kreativitas dan berkembangnya skill, para anggota Preman Super juga lebih kompeten di masing-masing bidang yang mereka tekuni karena didalam organisasi ini para anggota diberikan pendidikan dan diikut sertakan dalam pelatihan-pelatihan yang biasa diadakan oleh dinas terkait. Organisasi Preman Super berdiri dengan harapan dapat membuat wanita sadar bahwa mereka memiliki potensi dan kemampuan untuk dikembangkan dan juga diasah demi terciptanya perempuan-perempuan tangguh, percaya diri, dan mampu berdaya saing yang unggul.

\section{Visi, Misi dan Inspirasi Preman Super}

a. Visi: Menjadi Komunitas UMKM yang berpengaruh dalam menumbuhkan dan membesarkan anggota UMKM Preman Super khususnya dan UMKM secara luas yang berkualitas.

b. Misi :

1) Menumbuhkan solidaritas dan rasa memiliki Komunitas UMKM Preman Super diantara anggota Komunitas.

2) Membangun sistem dan perilaku yang positif serta mengacu pada prinsip-prinsip manajemen yang modern.

3) Meningkatkan kapasitas anggota guna mendukung gerakan ekonomi kreatif. 
4) Mengembangkan sumber daya komunikasi dan kerjasama dengan berbagai pihak guna menciptakan sinergi.

5) Membesarkan anggota komunitas UMKM Preman Super menjadi suatu usaha yang mempunyai pengetahuan dan keterampilan sesuai bidangnya.

c. Inspirasi Preman Super:

Enlighten (Mencerahkan): Memberikan pencerahan untuk membuka wawasan dan pikiran kepada para perempuan supaya percaya diri, berfikir maju, dan mampu mengarah kreativitas mereka tanpa mengabaikan peran dan fungsinya sebagai ibu dan istri dalam keluarga).

Educate (Mengajarkan): Mendorong terciptanya kondisi yang merangsang terjadinya proses saling berbagi dan saling melakukan pembelajaran, agar para perempuan lebih percaya diri dalam mendidik dan menciptakan lingkungan yang baik dan sehat bagi anak-anak serta keluarganya.

Empower (Memberdayakan): Memberikan kesempatan dan dukungan untuk mendorong para perempuan agar menjadi percaya diri dalam mengembangkan bakat dan keterampilannya. Tujuannya agar mereka lebih mandiri dan bisa turut berperan memberikan sumbangsih memberdayakan keluarga maupun masyarakat sekitarnya.

\section{Tujuan Berdirinya Organisasi}

Tujuan didirikannya organisasi sosial Preman Super adalah meningkatkan kesejahteraan masyarakat tanpa membedakan gender, agama, ras dan juga golongan. Tetapi pada hakikatnya, tujuan utama organisasi Preman Super adalah:

a. Memperjuangkan dan membela hak-hak anggota untuk memperoleh perlindungan sosial serta meningkatkan kesejahteraan anggota dan keluarganya.

b. Meningkatkan kesadaran kritis dan kemampuan anggota dalam mengatasi permasalahannya.

c. Berperan aktif menggali dan memberdayakan potensi sumberdaya ekonomi yang ada di masyarakat yang kemudian secara kreatif dan professional dapat menciptakan karya kedalam bentuk wirausaha yang mandiri.

d. Menciptakan lapangan kerja dan meningkatkan kesejahteraan anggota pada khususnya dan masyarakat pada umumnya.

e. Mempererat persatuan, semangat gotong royong dan kebersamaan anggota.

3. Asas, Landasan dan Sifat Berdirinya Organisasi

a. Preman Super berazaskan kepada keutuhan Hak Azasi Manusia universal dengan lebih mengedepankan semangat gotong royong, kekeluargaan, kebersamaan dan musyawarah mufakat dalam pelaksanaannya.

b. Preman Super berlandaskan Pancasila dan Undang-Undang Dasar 1945.

c. Preman Super bersifat Independen, terbuka dan demokratis, tidak terlibat dalam kepentingan dan kegiatan politik praktis, terorisme dan hal-hal yang berbau SARA.

Keberadaan suatu instansi atau suatu organisasi tidak lepas dari adanya suatu struktur yang terdapat didalamnya. Dalam pembentukan organisasi Preman Super diperlukan adanya struktur organisasi sebagai penempatan posisi atau pengkoordinasian agar dapat mengatur ketertiban dan kelancaran kegiatan yang diterapkan dalam organisasi Preman Super. Begitu juga dengan organisasi Preman Super yang dalam menjalankan tugas-tugas organisasi diperlukan adanya sturktur yang memudahkan pengorganisasian. Adapun struktur organisasi Preman Super adalah sebagi berikut: 
Tabel 1 Struktur Organisasi Preman Super

\begin{tabular}{|c|c|}
\hline No. & Jabatan \\
\hline & PUSAT \\
\hline 1 & Pimpinan \& Pembina \\
\hline 2 & Sekretaris \\
\hline 3 & Bendahara \\
\hline & WILAYAH KOTA MALANG \\
\hline 1 & Ketua \\
\hline 2 & Sekretaris \\
\hline 3 & Bendahara \\
\hline & Divisi-divisi \\
\hline 1 & Divisi Advokasi \\
\hline 2 & Divisi Pendidikan \& Pelatihan \\
\hline 3 & Divisi Ekonomi \\
\hline 4 & Divisi Data \& Info \\
\hline 5 & Divisi Pengorganisasian \\
\hline & Bidang-bidang \\
\hline 1 & Bidang Hubungan Masyarakat \\
\hline 2 & Bidang Marketing Online \\
\hline 3 & Bidang Pameran \\
\hline 4 & Bidang Produk Manmin \\
\hline 5 & Bidang Produk Non Manmin \\
\hline 6 & Bidang Jasa \\
\hline 7 & Bidang Kesehatan \\
\hline 8 & Bidang Lingkungan \\
\hline 9 & Bidang Keagamaan \\
\hline 10 & Bidang Seni \& Budaya \\
\hline & WILAYAH KABUPATEN MALANG \\
\hline 1 & Ketua \\
\hline 2 & Sekretaris \\
\hline 3 & Bendahara \\
\hline & Divisi-divisi \\
\hline 1 & Divisi Advokasi \\
\hline 2 & Divisi Pendidikan \& Pelatihan \\
\hline 3 & Divisi Ekonomi \\
\hline 4 & Divisi Data \& Info \\
\hline 5 & Divisi Pengorganisasian \\
\hline & Bidang-bidang \\
\hline 1 & Bidang Hubungan Masyarakat \\
\hline 2 & Bidang Marketing Online \\
\hline 3 & Bidang Pameran \\
\hline 4 & Bidang Produk Manmin \\
\hline 5 & Bidang Produk Non Manmin \\
\hline 6 & Bidang Kesehatan \\
\hline 7 & Bidang Lingkungan \\
\hline 8 & Bidang Keagamaan \\
\hline 9 & Bidang Seni \& Budaya \\
\hline
\end{tabular}


Pendidikan adalah pembelajaran, pengetahuan, keterampilan, dan kebiasaan sekelompok orang yang diturunkan dari satu generasi ke generasi berikutnya melalui pengajaran, pelatihan, atau penelitian. Pendidikan sering terjadi di bawah bimbingan orang lain, tetapi juga memungkinkan secara otodidak. Setiap pengalaman yang memiliki efek formatif pada cara orang berpikir, merasa, atau tindakan dapat dianggap pendidikan. Pendidikan memiliki peranan penting bagi kehidupan manusia, karena manusia wajib berpendidikan dan memiliki etika yang baik dalam mengarungi kehidupan, baik antar individu atau individu dengan kelompok agar manusia memiliki kesetaraan derajat tanpa ada yang berkuasa satu sama lain dan mampu bersaing secara sehat.

Preman Super merupakan sebuah organisasi sosial yang tidak hanya bertujuan pada pemberdayaan perempuan semata, tetapi juga berfokus pada segi pendidikan. Seperti yang telah dijelaskan oleh pembina sekaligus pendiri organisasi Preman Super yang mengatakan bahwa Preman Super juga sudah menerapkan nilai-nilai pendidikan dengan membagi dua macam jenis, yaitu pendidikan internal dan eksternal, yang dimaksud dengan pendidikan internal adalah para anggota perempuan diberikan pelatihan, dibekali ilmu pengetahuan dan juga diberikan kebebasan untuk mengasah keterampilan sesuai dengan potensi yag dimilikinya. Pendidikan internal yang lain adalah program trainer of trainer atau istilahnya adalah anggota yang sudah mahir/berpengalaman bisa memberikan pelatihan kepada anggota baru, hal itu sesuai dengan konsep dan proses pemberdayaan.

Menurut hasil wawancara peneliti dengan Ibu Peni Budi Astuti, pendiri sekaligus pembina organisasi Preman Super mengenai pendidikan internal: "kalau pendidikannya ya, trainer of trainer itu juga mas, jadi anggota yang sudah mahir itu melatih anggota yang lain, itu merupakan bentuk program. Karena pemberdayaan itu kan memang begitu konsepnya, jadi mereka diikutkan pelatihan, yang ikut pelatihan ganti melatih yang belum bisa".

Kemudian untuk pendidikan eksternal yakni beberapa anggotanya yang sudah memiliki pengalaman atau memiliki keahlian tertentu akan diikutsertakan dalam pelatihan-pelatihan yang diadakan oleh dinas terkait yang telah menjadi mitra kerja dari Preman Super. Dalam pelatihan itu para anggota diberikan kesempatan untuk mengembangkan bakat sesuai bidangnya, sebagai misal, para anggota yang hobi pada bidang memasak, maka mereka akan diikutsertakan pada pelatihan memasak dari dinas terkait dan dilakukan setiap bulan sekali.

Namun bila dilihat dari nilai Sosial dan Ekonomi, hal yang dapat dipetik dari keberadaan organisasi Preman Super adalah sebuah keuntungan karena telah memberikan sebuah wadah atau fasilitas bagi perempuan, gunanya adalah sebagai tempat berkumpul, sharing, berbagi pengalaman dan juga sebagai media komunikasiyang memberikan dampak yang sangat positif. Adapun beberapa jenis kegiatan pelatihan yang diberikan seperti memasak, membuat handicraft (kerajinan), fashion, dan juga kesenian. Melalui program pelatihan yang diberikan dan dari perkumpulan itulah para perempuan diberikan kebebasan untuk mengeluarkan potensinya dan juga kreativitasnya sehingga mereka dapat meningkatkan ilmunya dan mampu menghasilkan sesuatu yang bernilai jual yang nantinya bisa memberikan pengaruh yang signifikan bagi pola kehidupannya dan tercapainya kemandirian secara ekonomi.

Menurut hasil wawancara peneliti dengan Ibu Peni Budi Astuti, pendiri sekaligus pembina organisasi Preman Super mengenai peran pendidikan non formal 
dalam pengembangan sosial ekonomi dalam organisasi Preman Super: "nanti kedepannya Preman Super akan menjadi induk atau perusahaannya yang membantu menjadi reseller dari para anggota mas, meskipun masih digodok karena hanya akan memakai satu nama seperti Indofood gitu mas, item produknya kan macem-macem ada kecap, ada mie dan sebagainya, nah kita mau pake brand Preman Super, nanti ya dikemas oleh Preman Super tapi namanya dari pemilik masing-masing, jadi umapamanya nanti misalnya produk tiwul hitam merknya putih ya putih tapi dikemas oleh Preman Super, karena kita pengen menonjolkan Preman Supernya, jadi menyontoh perusahaan-perusahaan besar yang bisa menjadi resellernya perusahaan kecil, karena kita menganggap ibu-ibu sudah memiliki kegiatan masing-masing, karena masih kecilkecil itu kan memang dalam hal pemasaran kan masih dalam taraf berjuang kan, jadi bagaimana teknik marketing itu gimana, menjualnya kemana, segmen pasar yang diinginkan itu kemana, nah organisasi ini memikirkan itu bagaimana kalau menjadi media dari para anggota untuk menjadi perusahaan bagi anggota yang penting kan saling menguntungkan ya mas, ya tapi ini masih jadi godokan karena masih ada pro dan kontra dari semua anggota mas".

Berdasarkan paparan data diatas dapat dijelaskan bahwa peran pendidikan non formal berbasis sosial ekonomi pada organisasi Preman Super adalah secara luas telah dilaksanakan dengan baik, hal tersebut bisa dilihat dari hasil wawancara dengan Ibu Peni Budi Astuti selaku pendiri dan pembina organisasi Preman Super. Keberadaan organisasi Preman Super, secara tidak langsung telah membawa dampak yang positif bagi perkembangan Sosial dan Ekonomi bagi masyarakat, karena masyarakat (khususnya perempuan) telah diberikan kesempatan untuk mengembangkan skill dan potensinya melalui program-program dari Preman Super dan dapat mengenal, berinteraksi, saling berkomunikasi dengan perempuan lain yang sepemikiran dan memiliki visi yang sama yakni menuju kehidupan yang baik.

\section{Pembahasan}

Pendidikan adalah pembelajaran, pengetahuan, keterampilan, dan kebiasaan sekelompok orang yang diturunkan dari satu generasi ke generasi berikutnya melalui pengajaran, pelatihan, atau penelitian. Jalur pendidikan adalah wahana yang dilalui peserta didik untuk mengembangkan potensi diri dalam suatu proses pendidikan yang sesuai dengan tujuan pendidikan. Sistem pendidikan nasional mengakui ada 3 jalur pendidikan, yaitu: pendidikan formal, non formal, dan informal. Jalur pendidikan formal merupakan jalur pendidikan yang terstruktur dan berjenjang yang terdiri dari pendidikan dasar, pendidikan menengah, dan pendidikan tinggi. Jalur pendidikan nonformal adalah jalur pendidikan di luar pendidikan formal yang dapat dilaksanakan secara terstruktur dan berjenjang. Jalur pendidikan informal adalah jalur pendidikan keluarga dan lingkungan (Sumardiono, 2007).

Pendidikan merupakan suatu proses, dimana proses tersebut dapat berlangsung dimana dan kapan saja, tidak hanya dalam lingkungan yang formal seperti di sekolah atau kampus karena pendidikan tidak hanya sekolah atau kuliah. Perkembangan seseorang mulai dari kecil, remaja sampai dewasa, di sekolah, di masyarakat dan di rumah merupakan proses pendidikan yang menyeluruh.

Peran pendidikan non formal terhadap pengembangan Sosial Ekonomi dan Pemberdayaan Perempuan seperti yang disebutkan dalam bab empat merupakan sebuah bentuk peran yang membantu masyarakat meningkatkan kesejahteraan baik dalam bidang sosial maupun bidang ekonomi. Dalam sebuah upaya pemberdayaan masyarakat 
tidak akan berjalan lancar jika antara satu unsur dengan unsur yang lain tidak saling berkaitan, dalam hal ini adalah antara organisasi dengan anggota organisasi.

Menurut pandangan Hamojoyo, pendidikan non formal adalah usaha yang terorganisir secara sistematis dan kontinyu diluar sistem persekolahan, melalui hubungan sosial untuk membimbing individu, kelompok dan masyarakat, agar memiliki sikap dan cita-cita sosial (yang efektif) guna meningkatkan taraf hidup dibidang materi, sosial dan mental dalam rangka usaha mewujudkan kesejahteraan sosial.

Merujuk pendapat dari Hamojoyo, organisasi Preman Super sebagai tempat pendidikan non formal bisa dikatakan memiliki orientasi yang sama dan diselenggarakan secara bertahap, berkelanjutan, dan dilakukan diluar sistem persekolahan dan memiliki tugas untuk membina, memberikan pelatihan, memberikan wawasan dan juga nilai pendidikan yang berguna untuk mengembangkan aspek sosial dan ekonomi melalui program-program yang dijalankannya.

Dalam kamus Sosiologi dan Kependudukan mendefinisikan sosial adalah hubungan individu dengan lainnya dari jenis yang sama atau pada sejumlah individu untuk membentuk lebih banyak atau lebih sedikit kelompok yang terorganisir, juga tentang kecenderungan-kecenderungan dan impuls-impuls yang berhubungan dengan lainnya.

Jadi bisa disimpulkan bahwa pendidikan sosial adalah suatu proses yang diusahakan oleh orang dewasa terhadap anak secara sengaja dalam masyarakat untuk mendidik, membina, membangun individu dalam lingkungan sosial supaya ditengahtengah masyarakat, kelak anak mampu bergaul dan berperilaku baik terhadap sesama. Tentunya selalu berpegang pada akidah dan keimanan yang kokoh (Elly, 2006). Adapun unsur-unsur pendidikan sosial yang ada pada masyarakat yang harus diterapkan adalah: toleransi, solidaritas sosial, saling menghargai dan tolong menolong.

Dalam konteks Preman Super, disini para anggota sudah mampu menerapkan keempat unsur pendidikan, baik toleransi, solidaritas, saling menghargai, dan tolong menolong. Secara toleransi, para anggota memahami bahwa tidak serta merta mengikuti urusan orang lain. Secara solidaritas, para anggota sudah menyatu antar anggota dan menumbuhkan sikap saling menghargai agar terbina kerukunan serta tolong menolong dalam hal kebaikan.

Adapun pada prosesnya organisasi Preman Super selalu memberikan peluang bagi siapapun khususnya kaum perempuan untuk belajar, berkreasi dan menyalurkan bakat dan minatnya, sesuai dengan tujuannya yakni memperjuangkan dan membela hakhak anggota untuk memperoleh perlindungan sosial serta meningkatkan kesejahteraan anggota dan keluarganya, meningkatkan kesadaran kritis dan kemampuan anggota dalam mengatasi permasalahannya, berperan aktif menggali dan memberdayakan potensi sumberdaya ekonomi yang ada di masyarakat yang kemudian secara kreatif dan profesional dapat menciptakan karya kedalam bentuk wirausaha yang mandiri, menciptakan lapangan kerja dan meningkatkan kesejahteraan anggota pada khususnya dan masyarakat pada umumnya, serta mempererat persatuan, semangat gotong royong dan kebersamaan anggota.

Penjelasan diatas tersebut menunjukkan bahwa peran Preman Super adalah berfokus pada kesejahteraan masyarakat dan ekonomi kreatif khuhusnya perempuan, juga merupakan sebuah bentuk kontribusi yang nyata untuk mencetak perempuanperempuan handal yang memiliki kreativitas, keberanian, mandiri secara ekonomi dan mampu menjadi sumber perubahan bagi dirinya sendiri, keluarganya, masyarakat maupun bagi negara Indonesia. Terlebih, keberadaan Preman Super ditengah 
masyarakat juga harus diapesiasi karena telah membawa perubahan yang sangat signifikan dan dampak yang ditimbulkan juga sangat bermanfaat bagi seluruh lapisan masyarakat, mulai dari warga, sampai pemerintah Malang Raya.

\section{KESIMPULAN}

Preman Super sudah menerapkan nilai-nilai pendidikan dengan membagi dua macam jenis, yaitu pendidikan internal dan eksternal, yang dimaksud dengan pendidikan internal adalah para anggota perempuan diberikan pelatihan, dibekali ilmu pengetahuan dan juga diberikan kebebasan untuk mengasah keterampilan sesuai dengan potensi yang dimilikinya. Pendidikan internal yang lain adalah program trainer of trainer atau istilahnya adalah anggota yang sudah mahir/berpengalaman bisa memberikan pelatihan kepada anggota baru, hal itu sesuai dengan konsep dan proses pemberdayaan. Pendidikan eksternal yakni beberapa anggotanya yang sudah memiliki pengalaman atau memiliki keahlian tertentu akan diikutsertakan dalam pelatihanpelatihan yang diadakan oleh dinas terkait yang telah menjadi mitra kerja dari Preman Super. Dalam pelatihan itu para anggota diberikan kesempatan untuk mengembangkan bakat sesuai bidangnya, sebagai misal, para anggota yang hobi pada bidang memasak, maka mereka akan diikutsertakan pada pelatihan memasak dari dinas terkait dan dilakukan setiap bulan sekali.

Organisasi Preman Super selalu memberikan peluang bagi siapapun khususnya kaum perempuan untuk belajar, berkreasi dan menyalurkan bakat dan minatnya, sesuai dengan tujuannya yakni memperjuangkan dan membela hak-hak anggota untuk memperoleh perlindungan sosial serta meningkatkan kesejahteraan anggota dan keluarganya. Organisasi ini juga meningkatkan kesadaran kritis dan kemampuan anggota dalam mengatasi permasalahannya, berperan aktif menggali dan memberdayakan potensi sumberdaya ekonomi yang ada di masyarakat yang kemudian secara kreatif dan profesional dapat menciptakan karya kedalam bentuk wirausaha yang mandiri, menciptakan lapangan kerja dan meningkatkan kesejahteraan anggota pada khususnya dan masyarakat pada umumnya, serta mempererat persatuan, semangat gotong royong dan kebersamaan anggota.

Peran Preman Super adalah berfokus pada kesejahteraan masyarakat dan ekonomi kreatif khuhusnya perempuan, juga merupakan sebuah bentuk kontribusi yang nyata untuk mencetak perempuan-perempuan handal yang memiliki kreativitas, keberanian, mandiri secara ekonomi dan mampu menjadi sumber perubahan bagi dirinya sendiri, keluarganya, masyarakat maupun bagi negara Indonesia. Terlebih, keberadaan Preman Super ditengah masyarakat juga harus diapesiasi karena telah membawa perubahan yang sangat signifikan dan dampak yang ditimbulkan juga sangat bermanfaat bagi seluruh lapisan masyarakat, mulai dari warga, sampai pemerintah Malang Raya.

\section{DAFTAR PUSTAKA}

Adi, Isbandi Rukminto. (2003). Pemberdayaan, Pengembangan Masyarakat dan Intervensi Komunitas (Pengantar Pada Pemikiran dan Pendekatan Praktis). Jakarta : Lembaga Penerbit FE UI, Cetakan 1.

Alfitri. (2011). Community Development (Teori dan Aplikasi). Yogyakarta: Pustaka Pelajar, Cetakan 1 
Arikunto, Suharsimi. (2015). Prosedur Penelitian Suatu Pendekatan Praktek. Jakarta: Rineka Cipta.

Baswir, Revrisond. (2009). Manifesto Ekonomi Kerakyatan. Yogyakarta : Pustaka Pelajar.

Depertemen Pendidikan Dan Kebudayaan, Kamus Besar Bahasa Indonesia (Jakarta: Balai Pustaka,1982), hlm. 220.

Elly. (2006). Ilmu Sosial Budaya Dasar. Jakarta: Prenamedia Group.

Fakih, Mansour. (2003). Runtuhnya Teori Pembangunan dan Globalisasi. Yogyakarta: Insist Press dan Pustaka Pelajar.

Giddens, Anthony, dkk. (2008). Sosiologi Sejarah dan Berbagai Pemikirannya. Yogyakarta: Kreasi Wacana.

Hafidudin, Didin dan Tanjung, Hendri. (2003). Manajemen Syariah dalam Praktek. Jakarta : Gema Insani Press.

Hidayat, M. Arif, Anwar, Ali dan Hidayah, Noer. (2017). Pendidikan Non Formal Dalam Meningkatkan Keterampilan Anak Jalanan. Eudeena. Vol. 1 No. 1

Joesoef, Soelaiman. (1992). Konsep Dasar Pendidikan Luar Sekolah. Jakarta: Bumi Aksara.

Kamil, Mustofa. (2009). Pendidikan Non Formal (Pengembangan Melalui Pusat Kegiatan Belajar Mengajar (PKBM) di Indonesia (Sebuah Pembelajaran dari Kominkan Jepang). Bandung: Penerbit Alfabeta.

Kepmendagri No. 132/2003.

Miradj, Safitri Dan Sumarno. (2014). Pemberdayaan Masyarakat Miskin, Melalui Proses Pendidikan Nonformal, Upaya Meningkatkan Kesejahteraan Sosial Di Kabupaten Halmahera Barat Jurnal Pendidikan Dan Pemberdayaan Masyarakat, Volume 1 - Nomor 1

Narbuko, Cholid. (2007). Metodologi Penelitian. Jakarta: Bumi Aksara Sadono, Sukirno. 2006. Makroekonomi Teori Pengantar Edisi Ketiga. Jakarta: Raja Grafindo Persada.

Poerwadarminta, W.J.S. (2016). Kamus Umum Bahasa Indonesia.

Sapriya. 2009. Pendidikan IPS Konsep dan Pembelajaran. Bandung; Remaja Rosdakarya.

Soemitro, Ronny Hanitijo. (1985). Metodologi Penelitian Hukum. Jakarta: Ghalia Indonesia, Cetakan II.

Subagyo, Joko. (2004). Metode Penelitian Dalam Teori dan Praktek. Jakarta: Rineka Cipta, Cetakan Ke 4.

Suharto, Edi. (2009). Membangun Masyarakat Memberdayakan Rakyat. Bandung: PT. Refika Aditama, 2009.

Sumardiono. (2007). Homeschooling : A Leap For Better Learning. Jakarta: PT Elex Media Komputindo.

Tim Penyusun. (1992). Buku III: Pengantar Teknik Analisis Jender. Jakarta: Kantor Menteri Negara Urusan Peranan Wanita.

Usman, Husaini. (1996). Metodologi Penelitian Sosial. Jakarta: Bumi Aksara, Cetakan I.

Wulandari, Mustika. (2016). Tari Kiamat Dalam Pendidikan Nonformal Di Sanggar Intan Desa Kuripan Kabupaten Lampung Selatan. Skripsi. Universitas Lampung 